4

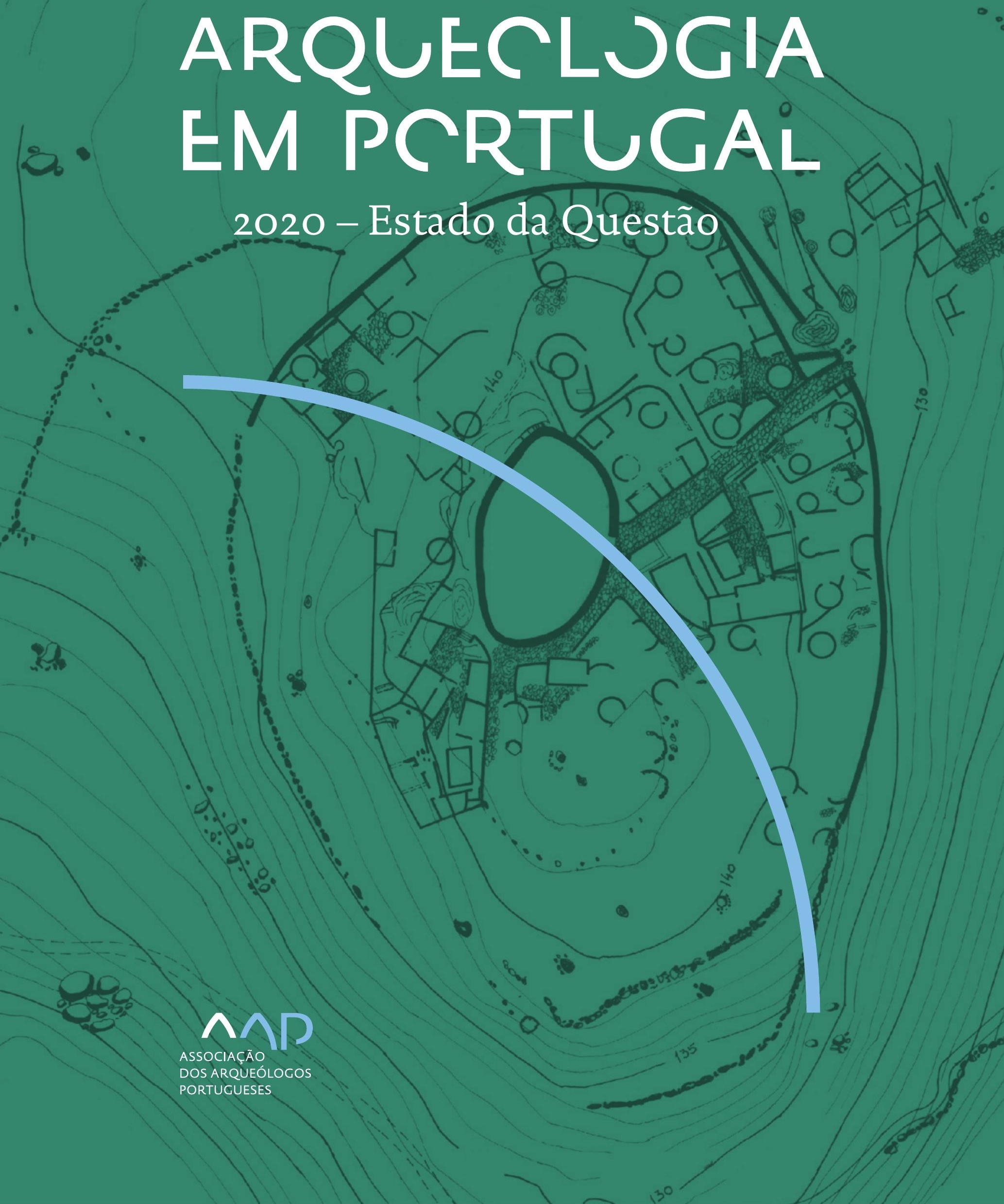


Coordenação editorial: José Morais Arnaud, César Neves e Andrea Martins Design gráfico: Flatland Design

AAP - ISBN: 978-972-9451-89-8

CITCEM - ISBN: 978-989-8970-25-1

Associação dos Arqueólogos Portugueses e CITCEM

Lisboa, 2020

O conteúdo dos artigos é da inteira responsabilidade dos autores. Sendo assim a Associação dos Arqueólogos Portugueses declina qualquer responsabilidade por eventuais equívocos ou questões de ordem ética e legal.

Desenho de capa:

Planta do castro de Monte Mozinho (Museu Municipal de Penafiel).

\section{$\hat{\wedge} \mathrm{P}$}

DOS ARQUEÓLOGOS PORTUGUESES

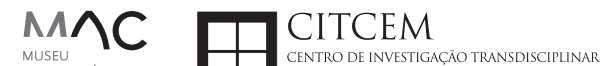
MUSEU
ARQUELLÓGICO
DO CARMO
U.PORTO

FLUP FACULDADE DE LETRAS
UNIVERSIDADE DO PORTO

Apoio

EC para a Ciência 


\section{Índice}

15 Prefácio

José Morais Arnaud

\section{Historiografia e Teoria}

17 Território, comunidade, memória e emoção: a contribuição da história da arqueologia (algumas primeiras e breves reflexões)

Ana Cristina Martins

25 Como descolonizar a arqueologia portuguesa?

Rui Gomes Coelho

41 Arqueologia e Modernidade: uma revisitação pessoal e breve de alguns aspetos da obra homónima de Julian Thomas de 2004

Vítor Oliveira Jorge

57 Dados para a História das Mulheres na Arqueologia portuguesa, dos finais do século XIX aos inícios do século XX: números, nomes e tabelas

Filipa Dimas / Mariana Diniz

73 Retractos da arqueologia portuguesa na imprensa: (in)visibilidades no feminino

Catarina Costeira / Elsa Luís

85 Arqueologia e Arqueólogos no Norte de Portugal Jacinta Bugalhão

101 Vieira Guimarães (1864-1939) e a arqueologia em Tomar: uma abordagem sobre o território e as gentes

João Amendoeira Peixoto / Ana Cristina Martins

115 Os memoráveis? A arqueologia algarvia na imprensa nacional e regional na presente centúria (2001-2019): características, visões do(s) passado(s) e a arqueologia

enquanto marca

Frederico Agosto / João Silva

129 A Evolução da Arqueologia Urbana e a Valorização Patrimonial no Barlavento Algarvio: Os casos de Portimão e Silves

Artur Mateus / Diogo Varandas / Rafael Boavida

\section{Gestão, Valorização e Salvaguarda do Património}

145 O Caderno Reivindicativo e as condições de trabalho em Arqueologia Miguel Rocha / Liliana Matias Carvalho / Regis Barbosa / Mauro Correia / Sara Simões / Jacinta Bugalhão / Sara Brito / Liliana Veríssimo Carvalho / Richard Peace / Pedro Peça / Cézer Santos

155 Os Estudos de Impacte Patrimonial como elemento para uma estratégia sustentável de minimização de impactes no âmbito de reconversões agrícolas Tiago do Pereiro

165 Salvaguarda de Património arqueológico em operações florestais: gestão e sensibilização Filipa Bragança / Gertrudes Zambujo / Sandra Lourenço / Belém Paiva / Carlos Banha / Frederico Tatá Regala / Helena Moura / Jacinta Bugalhão / João Marques / José Correia / Pedro Faria / Samuel Melro

179 Os valores do Património: uma investigação sobre os Sítios Pré-históricos de Arte Rupestre do Vale do Rio Côa e de Siega Verde José Paulo Francisco 
189 Conjugando recursos arqueológicos e naturais para potenciar as visitas ao Geoparque Litoral de Viana do Castelo (Noroeste de Portugal)

Hugo A. Sampaio / Ana M.S. Bettencourt / Susana Marinho / Ricardo Carvalhido

203 Áreas de Potencial Arqueológico na Região do Médio Tejo: Modelo Espacial Preditivo Rita Ferreira Anastácio / Ana Filipa Martins / Luiz Oosterbeek

223 Património Arqueológico e Gestão Territorial: O contributo da Arqueologia para a revisão do PDM de Avis

Ana Cristina Ribeiro

237 A coleção arqueológica do extinto Museu Municipal do Porto - Origens, Percursos e Estudos

Sónia Couto

251 Valpaços - uma nova carta arqueológica

Pedro Pereira / Maria de Fátima Casares Machado

263 Arqueologia na Cidade de Peniche

Adriano Constantino / Luís Rendeiro

273 Arqueologia Urbana: a cidade de Lagos como caso de Estudo Cátia Neto

285 Estratégias de promoção do património cultural subaquático nos Açores. O caso da ilha do Faial

José Luís Neto / José Bettencourt / Luís Borges / Pedro Parreira

297 Carta Arqueológica da Cidade Velha: Uma primeira abordagem

Jaylson Monteiro / Nireide Tavares / Sara da Veiga / Claudino Ramos / Edson Brito /

Carlos Carvalho / Francisco Moreira / Adalberto Tavares

311 Antropologia Virtual: novas metodologias para a análise morfológica e funcional Ricardo Miguel Godinho / Célia Gonçalves

\section{Didáctica da Arqueologia}

327 Como os projetos de Arqueologia podem contribuir para uma comunidade culturalmente mais consciente Alexandra Figueiredo / Claúdio Monteiro / Adolfo Silveira / Ricardo Lopes

337 Educação Patrimonial - Um cidadão esclarecido é um cidadão ativo! Ana Paula Almeida

351 A aproximação da Arqueologia à sala de aula: um caso de estudo no $3^{\circ}$ ciclo do Ensino Básico Luís Serrão Gil

363 Arqueologia 3.o - Pensar e comunicar a Arqueologia para um futuro sustentável Mónica Rolo

377 “Conversa de Arqueólogos" - Divulgar a Arqueologia em tempos de Pandemia Diogo Teixeira Dias

389 Escola Profissional de Arqueologia: desafios e oportunidades Susana Nunes / Dulcineia Pinto / Júlia Silva / Ana Mascarenhas

399 Os Museus de Arqueologia e os Jovens: a oferta educativa para o público adolescente Beatriz Correia Barata / Leonor Medeiros

411 O museu universitário como mediador entre a ciência e a sociedade: o exemplo da secção de arqueologia no Museu de História Natural e da Ciência da Universidade do Porto (MHNC-UP)

Rita Gaspar 
421 Museu de Lanifícios: Real Fábrica de Panos. Atividades no âmbito da Arqueologia Beatriz Correia Barata / Rita Salvado

427 Arqueologia Pública e o caso da localidade da Mata (Torres Novas) Cláudia Manso / Ana Rita Ferreira / Cristiana Ferreira / Vanessa Cardoso Antunes

431 Do sítio arqueológico ao museu: um percurso (também) didático Lídia Fernandes

447 Estão todos convidados para a Festa! E para dançar também... O projecto do Serviço Educativo do Museu Arqueológico do Carmo na $5^{\underline{a}}$ Edição da Festa da Arqueologia Rita Pires dos Santos

459 O “Clã de Carenque”, um projeto didático de arqueologia Eduardo Gonzalez Rocha

469 Mediação cultural: peixe que puxa carroça nas Ruínas Romanas de Troia Inês Vaz Pinto / Ana Patrícia Magalhães / Patrícia Brum / Filipa Santos

481 Didática Arqueológica, experiências do Projeto Mértola Vila Museu Maria de Fátima Palma / Clara Rodrigues / Susana Gómez / Lígia Rafael

\section{Arte Rupestre}

497 Os inventários de arte rupestre em Portugal Mila Simões de Abreu

513 O projeto FIRST-ART - conservação, documentação e gestão das primeiras manifestações de arte rupestre no Sudoeste da Península Ibérica: as grutas do Escoural e Maltravieso Sara Garcês / Hipólito Collado / José Julio García Arranz / Luiz Oosterbeek / António Carlos Silva / Pierluigi Rosina / Hugo Gomes / Anabela Borralheiro Pereira / George Nash / Esmeralda Gomes / Nelson Almeida / Carlos Carpetudo

523 Trabalhos de documentação de arte paleolítica realizados no âmbito do projeto PalæoCôa André Tomás Santos / António Fernando Barbosa / Luís Luís / Marcelo Silvestre / Thierry Aubry

537 Imagens fantasmagóricas, silhuetas elusivas: as figuras humanas na arte do Paleolítico Superior da região do Côa Mário Reis

$55^{1}$ Os motivos zoomórficos representados nas placas de tear de Vila Nova de São Pedro (Azambuja, Portugal) Andrea Martins / César Neves / José M. Arnaud / Mariana Diniz

571 Arte Rupestre do Monte de Góios (Lanhelas, Caminha). Síntese dos resultados dos trabalhos efectuados em 2007-2009 Mário Varela Gomes

599 Gravuras rupestres de barquiformes no Monte de S. Romão, Guimarães, Noroeste de Portugal Daniela Cardoso

613 Círculos segmentados gravados na Bacia do Rio Lima (Noroeste de Portugal): contributos para o seu estudo Diogo Marinho / Ana M.S. Bettencourt / Hugo Aluai Sampaio

631 Equídeos gravados no curso inferior do Rio Mouro, Monção (NW Portugal). Análise preliminar Coutinho, L.M. / Bettencourt, A.M.S / Sampaio, Hugo A.S

645 Paletas na Arte Rupestre do Noroeste de Portugal. Inventário preliminar Bruna Sousa Afonso / Ana M. S. Bettencourt / Hugo A. Sampaio 


\section{Pré-História}

661 O projeto Miño/Minho: balanço de quatro anos de trabalhos arqueológicos Sérgio Monteiro-Rodrigues / João Pedro Cunha-Ribeiro / Eduardo Méndez-Quintas / Carlos Ferreira / Pedro Xavier / José Meireles / Alberto Gomes / Manuel Santonja / Alfredo Pérez-González

677 A ocupação paleolítica da margem esquerda do Baixo Minho: a indústria lítica do sítio de Pedreiras 2 (Monção, Portugal) e a sua integração no contexto regional Carlos Ferreira / João Pedro Cunha-Ribeiro / Sérgio Monteiro-Rodrigues / Eduardo Méndez-Quintas / Pedro Xavier / José Meireles / Alberto Gomes / Manuel Santonja / Alfredo Pérez-González

693 O sítio acheulense do Plistocénico médio da Gruta da Aroeira Joan Daura / Montserrat Sanz / Filipa Rodrigues / Pedro Souto / João Zilhão

703 As sociedades neandertais no Barlavento algarvio: modelos preditivos com recurso aos SIG

Daniela Maio

715 A utilização de quartzo durante o Paleolítico Superior no território dos vales dos rios Vouga e Côa

Cristina Gameiro / Thierry Aubry / Bárbara Costa / Sérgio Gomes / Luís Luís / Carmen Manzano / André Tomás Santos

733 Uma perspetiva diacrónica da ocupação do concheiro do Cabeço da Amoreira (Muge, Portugal) a partir da tecnologia lítica Joana Belmiro / João Cascalheira / Célia Gonçalves

745 Novos dados sobre a Pré-história Antiga no concelho de Palmela. A intervenção arqueológica no sítio do Poceirão I

Michelle Teixeira Santos

757 Problemas em torno de Datas Absolutas Pré-Históricas no Norte do Alentejo Jorge de Oliveira

771 Povoamento pré-histórico nas áreas montanhosas do NO de Portugal: o Abrigo 1 de Vale de Cerdeira Pedro Xavier / José Meireles / Carlos Alves

783 Apreciação do povoamento do Neolítico Inicial na Baixa Bacia do Douro. A Lavra I (Serra da Aboboreira) como caso de estudo Maria de Jesus Sanches

797 O Processo de Neolitização na Plataforma do Mondego: os dados do Sector C do Outeiro dos Castelos de Beijós (Carregal do Sal)

João Carlos de Senna-Martinez / José Manuel Quintã Ventura / Andreia Carvalho / Cíntia Maurício

823 Novos trabalhos na Lapa da Bugalheira (Almonda, Torres Novas) Filipa Rodrigues / Pedro Souto / Artur Ferreira / Alexandre Varanda / Luís Gomes / Helena Gomes / João Zilhão

837 A pedra polida e afeiçoada do sítio do Neolítico médio da Moita do Ourives (Benavente, Portugal)

César Neves

857 Casal do Outeiro (Encarnação, Mafra): novos contributos para o conhecimento do povoamento do Neolítico final na Península de Lisboa.

Cátia Delicado / Carlos Maneira e Costa / Marta Miranda / Ana Catarina Sousa

873 Stresse infantil, morbilidade e mortalidade no sítio arqueológico do Neolítico Final/ Calcolítico ( $4^{\circ}$ e $3^{\circ}$ milénio a.C.) do Monte do Carrascal 2 (Ferreira do Alentejo, Beja) Liliana Matias de Carvalho / Sofia N. Wasterlain 
885 Come together: O Conjunto Megalítico das Motas (Monção, Viana do Castelo) e as expressões Campaniformes do Alto Minho Ana Catarina Basílio / Rui Ramos

899 Trabalhos arqueológicos no sítio Calcolítico da Pedreira do Poio Carla Magalhães / João Muralha / Mário Reis / António Batarda Fernandes

913 O sítio arqueológico de Castanheiro do Vento. Da arquitectura do sítio à arquitectura de um território João Muralha Cardoso

925 Estudo zooarqueológico das faunas do Calcolítico final de Vila Nova de São Pedro (Azambuja, Portugal): Campanhas de 2017 e 2018 Cleia Detry / Ana Catarina Francisco / Mariana Diniz / Andrea Martins / César Neves / José Morais Arnaud

943 As faunas depositadas no Museu Arqueológico do Carmo provenientes de Vila Nova de São Pedro (Azambuja): as campanhas de 1937 a 1967 Ana Catarina Francisco / Cleia Detry / César Neves / Andrea Martins / Mariana Diniz / José Morais Arnaud

959 Análise funcional de material lítico em sílex do castro de Vila Nova de S. Pedro (Azambuja, Portugal): uma primeira abordagem Rafael Lima

971 O recinto da Folha do Ouro 1 (Serpa) no contexto dos recintos de fossos calcolíticos alentejanos

António Carlos Valera / Tiago do Pereiro / Pedro Valério / António M. Monge Soares

\section{Proto-História}

987 Produção de sal marinho na Idade do Bronze do noroeste Português. Alguns dados para uma reflexão

Ana M. S. Bettencourt / Sara Luz / Nuno Oliveira / Pedro P. Simões / Maria Isabel C. Alves / Emílio Abad-Vidal

1001 A estátua-menir do Pedrão ou de São Bartolomeu do Mar (Esposende, noroeste de Portugal) no contexto arqueológico da fachada costeira de entre os rios Neiva e Cávado Ana M. S. Bettencourt / Manuel Santos-Estévez / Pedro Pimenta Simões / Luís Gonçalves

1015 O Castro do Muro (Vandoma/Baltar, Paredes) - notas para uma biografia de ocupação da Idade do Bronze à Idade Média

Maria Antónia D. Silva / Ana M. S. Bettencourt / António Manuel S. P. Silva / Natália Félix

1031 Do Bronze Final à Idade Média - continuidades e hiatos na ocupação de Povoados em Oliveira de Azeméis João Tiago Tavares / Adriaan de Man

1041 As faunas do final da Idade do Bronze no Sul de Portugal: leituras desde o Outeiro do Circo (Beja)

Nelson J. Almeida / Íris Dias / Cleia Detry / Eduardo Porfírio / Miguel Serra

1055 A Espada do Monte das Oliveiras (Serpa) - uma arma do Bronze Pleno do Sudoeste Rui M. G. Monge Soares / Pedro Valério / Mariana Nabais / António M. Monge Soares

1065 São Julião da Branca (Albergaria-a-Velha) - Investigação e valorização de um povoado do Bronze Final

António Manuel S. P. Silva / Paulo A. P. Lemos / Sara Almeida e Silva / Edite Martins de Sá

1083 Do castro de S. João ao Mosteiro de Santa Clara: notícia de uma intervenção arqueológica, em Vila do Conde Rui Pinheiro 
1095 O castro de Ovil (Espinho), um quarto de século de investigação - resultados e questões em aberto

Jorge Fernando Salvador / António Manuel S. P. Silva

1111 O Castro de Salreu (Estarreja), um povoado proto-histórico no litoral do Entre Douro e Vouga

Sara Almeida e Silva / António Manuel S. P. Silva / Paulo A. P. Lemos / Edite Martins de Sá

1127 Castro de Nossa Senhora das Necessidades (Sernancelhe): uma primeira análise artefactual Telma Susana O. Ribeiro

${ }_{1141}$ A cividade de Bagunte. O estado atual da investigação Pedro Brochado de Almeida

1153 Zoomorfos na cerâmica da Idade do Ferro no NW Peninsular: inventário, cronologias e significado Nuno Oliveira / Cristina Seoane

1163 Vasos gregos em Portugal: diferentes maneiras de contar a história do intercâmbio cultural na Idade do Ferro

Daniela Ferreira

1175 Os exotica da necrópole da Idade do Ferro do Olival do Senhor dos Mártires (Alcácer do Sal) no seu contexto regional

Francisco B. Gomes

\section{Antiguidade Clássica e Tardia}

1191 O uso de madeira como combustível no sítio da Quinta de Crestelos (Baixo Sabor): da Idade do Ferro à Romanização Filipe Vaz / João Tereso / Sérgio Simões Pereira / José Sastre / Javier Larrazabal Galarza / Susana Cosme / José António Pereira / Israel Espi

1207 Cultivos de Época Romana no Baixo Sabor: continuidade em tempos de mudança? João Pedro Tereso / Sérgio Simões Pereira / Filipe Santos / Luís Seabra / Filipe Vaz

1221 A casa romana na Hispânia: aplicação dos modelos itálicos nas províncias ibéricas Fernanda Magalhães / Diego Machado / Manuela Martins

1235 As pinturas murais romanas da Rua General Sousa Machado, n. ${ }^{5}$ 1, Chaves José Carvalho

1243 Trás do Castelo (Vale de Mir, Pegarinhos, Alijó) - Uma exploração agrícola romana do Douro

Tony Silvino / Pedro Pereira

1255 A sequência de ocupação no quadrante sudeste de Bracara Augusta: as transformações de uma unidade doméstica Lara Fernandes / Manuela Martins

1263 Os Mosaicos com decoração geométrica e geométrico-vegetalista dos sítios arqueológicos da área do Conuentus Bracaraugustanus. Novas abordagens quanto à conservação, restauro, decoração e datação Maria de Fátima Abraços / Licínia Wrench

1277 “Casa Romana” do Castro de São Domingos (Cristelos, Lousada): Escavação, Estudo e Musealização Paulo André de P. Lemos

1291 A arqueobotânica no Castro de Guifões (Matosinhos, Noroeste de Portugal): O primeiro estudo carpológico

Luís Seabra / Andreia Arezes / Catarina Magalhães / José Varela / João Pedro Tereso 
1305 Um Horreum Augustano na Foz do Douro (Monte do Castelo de Gaia, Vila Nova de Gaia) Rui Ramos

1311 Ponderais romanos na Lusitânia: padrões, formas, materiais e contextos de utilização Diego Barrios Rodríguez

1323 Um almofariz centro-itálico na foz do Mondego

Marco Penajoia

1335 Estruturas romanas de Carnide - Lisboa Luísa Batalha / Mário Monteiro / Guilherme Cardoso

1347 O contexto funerário do sector da "necrópole NO" da Rua das Portas de S. Antão (Lisboa): o espaço, os artefactos, os indivíduos e a sua interconectividade na interpretação do passado Sílvia Loja, José Carlos Quaresma, Nelson Cabaço, Marina Lourenço, Sílvia Casimiro, Rodrigo Banha da Silva, Francisca Alves-Cardoso

${ }_{1361}$ Povoamento em época Romana na Amadora - resultados de um projeto pluridisciplinar Gisela Encarnação / Vanessa Dias

1371 A Arquitectura Residencial em Mirobriga (Santiago do Cacém): contributo a partir de um estudo de caso Filipe Sousa / Catarina Felício

${ }_{1385}$ O fim do ciclo. Saneamento e gestão de resíduos nos edifícios termais de Mirobriga (Santiago do Cacém)

Catarina Felício / Filipe Sousa

1399 Balsa, Topografia e Urbanismo de uma Cidade Portuária Vítor Silva Dias / João Pedro Bernardes / Celso Candeias / Cristina Tété Garcia

1413 No Largo das Mouras Velhas em Faro (2017): novas evidências da necrópole norte de Ossonoba e da sua ocupação medieval Ricardo Costeira da Silva / Paulo Botelho / Fernando Santos / Liliana Nunes

1429 Instrumentos de pesca recuperados numa fábrica de salga em Ossonoba (Faro) Inês Rasteiro / Ricardo Costeira da Silva / Paulo Botelho

1439 A Necrópole Romana do Eirô, Duas Igrejas (Penafiel): intervenção arqueológica de 2016 Laura Sousa / Teresa Soeiro

1457 Ritual, descarte ou afetividade? A presença de Canis lupus familiaris na Necrópole Noroeste de Olisipo (Lisboa)

Beatriz Calapez Santos / Sofia Simões Pereira / Rodrigo Banha da Silva / Sílvia Casimiro / Cleia Detry / Francisca Alves Cardoso

1467 Dinâmicas económicas em Bracara na Antiguidade Tardia Diego Machado / Manuela Martins / Fernanda Magalhães / Natália Botica

1479 Cerâmicas e Vidros da Antiguidade Tardia do Edifício sob a Igreja do Bom Jesus (Vila Nova de Gaia) Joaquim Filipe Ramos

1493 Novos contributos para a topografia histórica de Mértola no período romano e na Antiguidade Tardia Virgílio Lopes

\section{8. Época Medieval}

1511 Cerâmicas islâmicas no Garb setentrional "português": algumas evidências e incógnitas Constança dos Santos / Helena Catarino / Susana Gómez / Maria José Gonçalves / Isabel Inácio / Gonçalo Lopes / Jacinta Bugalhão / Sandra Cavaco / Jaquelina Covaneiro / Isabel Cristina Fernandes / Ana Sofia Gomes 
1525 Contributo para o conhecimento da cosmética islâmica, em Silves, durante a Idade Média Rosa Varela Gomes

1537 Yábura e o seu território - uma análise histórico-arqueológica de Évora entre os séculos VIII-XII José Rui Santos

1547 A encosta sul do Castelo de Palmela - resultados preliminares da escavação arqueológica Luís Filipe Pereira / Michelle Teixeira Santos

1559 A igreja de São Lourenço (Mouraria, Lisboa): um conjunto de silos e de cerâmica medieval islâmica

Andreia Filipa Moreira Rodrigues

1571 O registo material de movimentações populacionais no Médio Tejo, durante os séculos XII-XIII. Dois casos de "sunken featured buildings", nos concelhos de Cartaxo e Torres Novas Marco Liberato / Helena Santos / Nuno Santos

1585 O nordeste transmontano nos alvores da Idade média. Notas para reflexão Ana Maria da Costa Oliveira

1601 Sepulturas escavadas na rocha do Norte de Portugal e do Vale do Douro: primeiros resultados do Projecto SER-NPVD

Mário Jorge Barroca / César Guedes / Andreia Arezes / Ana Maria Oliveira

1619 "Portucalem Castrum Novum" entre o Mediterrâneo e o Atlântico: o estudo dos materiais cerâmicos alto-medievais do arqueossítio da rua de D. Hugo, nํ. 5 (Porto) João Luís Veloso

1627 A Alta Idade Média na fronteira de Lafões: notas preliminares sobre a Arqueologia no Concelho de Vouzela

Manuel Luís Real / Catarina Tente

1641 Um conjunto cerâmico medieval fora de portas: um breve testemunho aveirense Susana Temudo

${ }_{1651}$ Os Lóios do Porto: uma perspetiva integrada no panorama funerário da Baixa Idade Média à Época Moderna em meios urbanos em Portugal

Ana Lema Seabra

1659 O Caminho Português Interior de Santiago como eixo viário na Idade Média Pedro Azevedo

1665 Morfologia Urbana: Um exercício em torno do Castelo de Ourém André Donas-Botto / Jaqueline Pereira

1677 Intervenção arqueológica na Rua Marquês de Pombal/Largo do Espírito Santo (Bucelas, Loures)

Florbela Estêvão / Nathalie Antunes-Ferreira / Dário Ramos Neves / Inês Lisboa

1691 O Cemitério Medieval do Poço do Borratém e a espacialidade funerária na cidade de Lisboa Inês Belém / Vanessa Filipe / Vasco Noronha Vieira / Sónia Ferro / Rodrigo Banha da Silva

1705 Um Espaço Funerário Conventual do séc. XV em Lisboa: o caso do Convento de São Domingos da Cidade Sérgio Pedroso / Sílvia Casimiro / Rodrigo Banha da Silva / Francisca Alves Cardoso

\section{9. Época Moderna e Contemporânea}

1721 Arqueologia Moderna em Portugal: algumas reflexões críticas em torno da quantificação de conjuntos cerâmicos e suas inferências históricas e antropológicas Rodrigo Banha da Silva / André Bargão / Sara da Cruz Ferreira

1733 Faianças de dois contextos entre os finais do século XVI e XVIII do Palácio dos Condes de Penafiel, Lisboa

Martim Lopes / Tomás Mesquita 
1747 Um perfil de consumo do século XVIII na foz do Tejo: O caso do Mercado da Ribeira, Lisboa Sara da Cruz Ferreira / Rodrigo Banha da Silva / André Bargão

1761 Os Cachimbos dos Séculos XVII e XVIII do Palácio Mesquitela e Convento dos Inglesinhos (Lisboa)

Inês Simão / Marina Pinto / João Pimenta / Sara da Cruz Ferreira / André Bargão / Rodrigo Banha da Silva

1775 "Tomar os fumos da erua que chamão em Portugal erua sancta». Estudo de Cachimbos provenientes da Rua do Terreiro do Trigo, Lisboa

Miguel Martins de Sousa / José Pedro Henriques / Vanessa Galiza Filipe

1787 Cachimbos de Barro Caulínitico da Sé da Cidade Velha (República de Cabo Verde)

Rodrigo Banha da Silva / João Pimenta / Clementino Amaro

1801 Algumas considerações sobre espólio não cerâmico recuperado no Largo de Jesus (Lisboa) Carlos Boavida

1815 Adereços de vidro, dos séculos XVI-XVIII, procedentes do antigo Convento de Santana de Lisboa (anéis, braceletes e contas)

Joana Gonçalves / Rosa Varela Gomes / Mário Varela Gomes

1837 Da ostentação, luxo e poder à simplicidade do uso quotidiano: arqueologia e simbologia de joias e adornos da Idade Moderna Portuguesa Jéssica Iglésias

1849 Os amuletos em Portugal - dos objetos às superstições: o coral vermelho Alexandra Vieira

1865 Cerâmicas de Vila Franca de Xira nos séculos XV e XVI Eva Pires

1879 «Não passa por teu o que me pertence». Marcas de individualização associadas a faianças do Convento de Nossa Senhora de Aracoeli, Alcácer do Sal Catarina Parreira / Íris Fragoso / Miguel Martins de Sousa

1891 Cerâmica de Leiria: alguns focos de produção

Jaqueline Pereira / André Donas-Botto

1901 Os Fornos na Rua da Biquinha, em Óbidos Hugo Silva / Filipe Oliveira

1909 A casa de Pêro Fernandes, contador dos contos de D. Manuel I: o sítio arqueológico da Silha do Alferes, Seixal (século XVI) Mariana Nunes Ferreira

1921 O Alto da Vigia (Sintra) e a vigilância e defesa da costa Alexandre Gonçalves / Sandra Santos

1937 O contexto da torre sineira da Igreja de Santa Maria de Loures Paulo Calaveira / Martim Lopes

1949 A Necrópole do Hospital Militar do Castelo de São Jorge e as práticas funerárias na Lisboa de Época Moderna Susana Henriques / Liliana Matias de Carvalho / Ana Amarante / Sofia N. Wasterlain

1963 SAND - Sarilhos Grandes Entre dois Mundos: o adro da Igreja e a Paleobiologia dos ossos humanos recuperados

Paula Alves Pereira / Roger Lee Jesus / Bruno M. Magalhães

1975 Expansão urbana da vila de Cascais no século XVII e XVIII: a intervenção arqueológica na Rua da Vitória no 15 a 17

Tiago Pereira / Vanessa Filipe

1987 Novos dados para o conhecimento do Urbanismo de Faro em época Moderna Ana Rosa 
1995 Um exemplo de Arqueologia Urbana em Alcoutim: o Antigo Edifício dos CTT Marco Fernandes / Marta Dias / Alexandra Gradim / Virgílio Lopes / Susana Gómez Martínez

2007 Palácio dos Ferrazes (Rua das Flores/Rua da Vitória, Porto): a cocheira de Domingos Oliveira Maia

Francisco Raimundo

2021 As muitas vidas de um edifício urbano: História, Arqueologia e Antropologia no antigo Recreatório Paroquial de Penafiel Helena Bernardo / Jorge Sampaio / Marta Borges

2035 O convento de Nossa Senhora da Esperança de Ponta Delgada: o contributo da arqueologia para o conhecimento de um monumento identitário João Gonçalves Araújo / N’Zinga Oliveira

2047 Arqueologia na ilha do Corvo... em busca da capela de Nossa Senhora do Rosário Tânia Manuel Casimiro / José Luís Neto / Luís Borges / Pedro Parreira

2059 Perdidos à vista da Costa. Trabalhos arqueológicos subaquáticos na Barra do Tejo Jorge Freire / José Bettencourt / Augusto Salgado

2071 Arqueologia marítima em Cabo Verde: enquadramento e primeiros resultados do projecto CONCHA

José Bettencourt / Adilson Dias / Carlos Lima / Christelle Chouzenoux / Cristóvão Fonseca / Dúnia Pereira / Gonçalo Lopes / Inês Coelho / Jaylson Monteiro / José Lima / Maria Eugénia Alves / Patrícia Carvalho / Tiago Silva

2085 Trabalhos arqueológicos na Cidade Velha (Ribeira Grande de Santiago, Cabo Verde): reflexões sobre um projecto de investigação e divulgação patrimonial André Teixeira / Jaylson Monteiro / Mariana Mateus / Nireide Tavares / Cristovão Fonseca / Gonçalo C. Lopes / Joana Bento Torres / Dúnia Pereira / André Bargão / Aurélie Mayer / Bruno Zélie / Carlos Lima / Christelle Chouzenoux / Inês Henriques / Inês Pinto Coelho / José Lima / Patrícia Carvalho / Tiago Silva

2103 A antiga fortificação de Quelba / Khor Kalba (E.A.U.). Resultados de quatro campanhas de escavações, problemáticas e perspectivas futuras Rui Carita / Rosa Varela Gomes / Mário Varela Gomes / Kamyar Kamyad

2123 Colónias para homens novos: arqueologia da colonização agrária fascista no noroeste ibérico Xurxo Ayán Vila / José Mạ . Señorán Martín 


\title{
ARQUEOLOGIA NA CIDADE DE PENICHE
}

\author{
Adriano Constantino ${ }^{1}$, Luís Rendeiro ${ }^{1}$
}

\begin{abstract}
RESUMO
A valorização e o conceito de interpretação do património têm variado ao longo dos últimos cem anos em Peniche. Até meados do século XX assistiu-se a uma destruição constante do património edificado (religioso e militar) em prol "do progresso". Como resposta a esta destruição e na tentativa de defender o património existente, na segunda metade do mesmo século surge a classificação de vários monumentos através da publicação de decretos-lei. No entanto o património arqueológico foi descuidado, e será preciso esperar pelo final do século XX e inícios do seguinte para a arqueologia urbana ganhar papel de destaque e fonte de informação. Palavras-chave: Peniche, Arqueologia, Património, Oeste, Portugal.
\end{abstract}

\begin{abstract}
The valuation and concept of heritage interpretation has changed over the last hundred years in Peniche. Until the middle of the 2oth century, there was a constant destruction of the built heritage (religious and military) in favor of "progress". In response to this destruction and in an attempt to defend the existing heritage, in the second half of the same century the classification of several monuments emerged through the publication of decree-laws. However, the archaeological heritage has been neglected, and it will be necessary to wait for the end of the 2oth century and the beginning of the next for urban archeology to gain a prominent role and source of information.
\end{abstract}

Keywords: Peniche, Archeology, Heritage, West, Portugal.

\section{INTRODUÇÃO}

A arqueologia das cidades é um ramo da arqueologia confundido, por vezes, com a arqueologia urbana, embora o objeto de estudo seja a cidade, esta última centra-se na escavação que está a ser realizada e toda a problemática da ocupação daquele espaço intervencionado. A arqueologia das cidades pretende compreender a urbe como um todo, O planeamento das cidades em Portugal ao longo do século XX alterou-se com a introdução de várias leis de defesa do património. A arqueologia das cidades vem consequentemente ganhando importância não só no planeamento das urbes mas na salvaguarda, valorização do património e produção de conhecimento. $\mathrm{O}$ estudo aqui apresentado procura analisar a arqueologia na cidade de Peniche, com base na recolha bibliográfica dos trabalhos arqueológicos realizados, de achados, e produção científica. Para tal foi imprescindível a pesquisa nos motores de busca Google e o Endovélico, no arquivo do jornal local A voz do Mar (de 1957 até 2016), de alguns números do Jornal de
Peniche (1980 a 1982), e do Correio Popular (20072009). Promoveu-se ainda às análises do Plano Director Municipal e da Carta Magna de Peniche de forma a compreender o papel traçado para a arqueologia na cidade.

\section{CONTEXTO GEOLÓGICO E GEOGRÁFICO}

O concelho de Peniche situa-se na região Oeste, distrito de Leiria, tendo como limites Norte e Sul os municípios de Óbidos e de Lourinhã respetivamente, e a Oeste com o oceano Atlântico, encontra-se dividido pelas freguesias de Atouguia da Baleia, Ferrel, Serra d'El Rei e Peniche. Na Carta Militar de Portugal, escala 1: 25 ooo, localiza-se na folha n. ${ }^{\circ} 337$ (Figura 1), enquanto na Carta Geológica de Portugal à escala 1:50 ooo corresponde à folha 26-C.

Em termos geomorfológicos o concelho localiza-se no extremo ocidental da Península Ibérica, na Orla Mesocenozóica Ocidental ou Lusitânica, uma mega bacia sedimentar oceânica desenvolvida a partir do Mesozoico na Margem Ocidental Ibérica pela frag-

1. Patrimonium - Centro de Estudos e Defesa do Património da Região de Peniche; Patrimoniumpeniche@outlook.com. 
mentação da Pangeia durante a abertura do Atlântico Norte (Kullberg \& alii 2006, p.317). Em termos de geologia, a carta explicativa de 1960 (França \& alii 1960) apresenta uma variedade de formações geológicas presentes no concelho. Formações que passam pelo "Complexo cristalofílico" e o Quaternário Moderno. As Berlengas inserem-se no grupo das rochas eruptivas bem como as Estelas, Medas e Cerro da Velha. Por fim, importa referir referir a existência de uma brecha vulcânica na Papôa.

Para a leitura da ocupação de Peniche é fundamental compreender a transformação geográfica ocorrida no território. A insularidade de Peniche encontra-se atestada na crónica da conquista de Lisboa aos mouros em 1147, da qual citamos: "No dia seguinte aportámos com felicidade à ilha de Peniche, distante do continente de 800 passos..." (Calado 1994).

O progressivo assoreamento do porto medieval de Atouguia verificado desde o século XV culmina com a criação de um istmo que ligaria Peniche ao continente no século XVI, transferindo o centro económico para a florescente localidade. Após a Restauração em 1640, face ao perigo iminente de um ataque espanhol, na zona leste de Peniche é construída uma muralha com os meios baluartes da Misericórdia, Calçada, São Vicente e Cambôa e o Baluarte da Ponte. Esta imponente construção irá em algumas partes assentar na antiga linha de costa. A leitura das cartas topográfica e geológica, permite verificar um conjunto de cotas muito próximas entre si a rondar os $5 \mathrm{~m}$, nos antigos lugares banhados pelo mar. Desta forma, a rua da Alegria, Av. 25 de Abril, Rua Alexandre Herculano, Lagoinha, Praça Jacob Rodrigues e Largo 5 de Outubro, delimitam o antigo esteio.

\section{A OCUPAÇÃO HUMANA}

Os trabalhos arqueológicos realizados em Peniche permitiram verificar a presença humana em Peniche desde a Pré-história. A gruta da Furninha, escavada ainda na segunda metade do século XIX por Nery Delgado, apresenta um conjunto importante de materiais atribuíveis ao Neolítico e Calcolítico (Cardoso e Carvalho, 2011) e um conjunto faunístico de grande relevância (Brugal \& alii 2012). A par deste local emblemático, destaca-se ainda a publicação nos anos 70 do século passado por Zbyszewski , de várias jazidas do Paleolítico em Peniche (Zbyszewski 1970).

A peugada humana só volta a ser identificada já em período romano. São vários os vestígios que se têm vindo a descobrir nos últimos 20 anos, desde uma olaria de produção de ânforas (Cardoso et all 2016), a possível área portuária (Neto \& alii 2007), e um cipo encontrado ainda no século XIX.

Após o fim da ocupação romana, o estado atual do conhecimento demonstra um hiato ocupacional terminado em 1340, através da construção de armazéns. O progressivo assoreamento do porto de Atouguia levará a uma gradual transferência económica e populacional para Peniche. Este desenvolvimento tem o apoio da coroa como demonstra o documento D. Manuel de 1505 sobre a doação de terrenos para a construção de habitações (Calado 1999, p. 26). Este crescimento irá se refletir em 1516 com a criação da paróquia de Santa Maria da Ajuda e no recenseamento de 1527 . Neste censo verifica-se um maior número de população em Peniche (Peniche de Cima 47 vizinhos, Peniche de Baixo 144) face à então sede de concelho, Atouguia da Baleia (121 vizinhos) (Calado 1991),

A leitura do recenseamento permite também verificar a existência dentro de Peniche de dois núcleos, Peniche de Cima e Peniche de Baixo, com predomínio deste último. Esta realidade demonstra um maior desenvolvimento e consequente concentração populacional em torno do porto. O florescimento de Peniche levará à criação ainda das paróquias de São Pedro e de São Sebastião culminando em 1609 com a elevação a vila e sede de concelho, separando-se administrativamente de Atouguia embora se regesse pelo mesmo foral.

Deste período datam importantes construções religiosas como o Convento do Bom Jesus, a igreja de São Pedro, a maior de todas, em finais do século XVI, a igreja da Misericórdia em 1629 e respetivo hospital e a ampliação igreja de Nossa Senhora da Ajuda em 1569. A necessidade de fortificar Peniche pela sua posição estratégica leva à construção em 1557 do Redondo, a génese da Fortaleza. Com a Guerra da Restauração assiste-se à construção de um importante conjunto de fortificações de que fazem parte os Fortes das Cabanas e da Luz e a cinta de muralhas, além da conclusão da Fortaleza. Afastado da vila é ainda construído no cabo Carvoeiro o forte de Nossa Senhora da Vitória (Calado 2000) (Figura 2).

Após estes acontecimentos o urbanismo pouco ou nada muda até ao século XIX, assistindo-se neste século à construção de novas fortificações no Porto Areia Norte e o fortim de Santo António no Campo da Torre, Peniche de Baixo (Calado 200o). Com a 
entrada no século XX o panorama de Peniche altera-se. Em 1910 instala-se a primeira fábrica de conservas de peixe seguida de outras indústrias conserveiras. A instalação das unidades fabris ocorre em terrenos periféricos da vila, normalmente terrenos agrícolas. O início do século fica marcado pela introdução da traineira em 1912 e mais tarde já nos anos 20 a sua motorização (Russo 2014).

Estes dois fatores, industrialização e desenvolvimento da pesca, serão responsáveis pela chegada de pescadores de todo o litoral para Peniche, aumentando a pressão demográfica. Raul Brandão na sua obra Pescadores caracteriza a situação de Peniche neste período como " horrível para mim porque é um tipo de pesca industrializada, o barracão, a fábrica, a caserna da sardinha..."(Brandão 2010).

Aos poucos são construídos bairros de pescadores e de operários, enquanto os armadores das embarcações, com os rendimentos da pesca, investem na remodelação das suas habitações, descaracterizando a zona histórica de Peniche de Baixo. Devido a este grande crescimento piscatório, o porto recebe importantes obras de alteração em finais de 1935. Este desenvolvimento portuário levará ao aumento do tráfego automóvel, associado ao escoamento do pescado, optando-se pelo alargamento da Avenida do Mar. As obras iniciam-se em 1950 com a destruição do topo da Cortina do Cais e com a construção de um novo paredão, aumentando desta forma a largura da Avenida. O Largo do Município sofre também alterações com a destruição de parte do meio baluarte da Misericórdia. Nesta década algum património edificado é demolido, como a capela de São Marcos, Paiol da Pólvora, os paços da Misericórdia e o forte de Nossa Senhora da Vitória (Cabo Carvoeiro), e assiste-se ao alargamento dos denominados portões de Peniche de Cima.

O pós 25 de Abril é marcado por um novo aumento da construção, surgindo novos bairros de forma a resolver o problema da habitabilidade em Peniche. Este novo período de expansão urbana avança para o interior da península ocupando os antigos terrenos agrícolas ladeados por muros de pedras solta. No lado oposto da frente abaluartada verificando-se a instalação de armazéns e indústria na zona da Prageira.

Desta forma podemos afirmar que são conhecidos, até agora, dois momentos de ocupação e urbanização de Peniche distintos. Uma em época clássica, vocacionada para o fabrico cerâmica utilitária e de ânforas para envase de produtos piscícolas. E outra que se inicia no final da Idade Média e que se prolongou até aos dias de hoje, caracterizada com a ascensão de Peniche a sede de concelho. Em ambas as situações as atividades marítimas são preponderantes.

\section{PENSAR A CIDADE E O PATRIMÓNIO}

O crescimento desordenado ao longo do século XX levou ao conceituado arquiteto nacional e nascido em Peniche, Paulino Montez, a realizar um plano de ordenamento para a península de Peniche, em 1974, e publicado em 1976, abordando o "Traçado da rede viária", o "traçado do zonamento" e, ainda, o "traçado do equipamento" (Gregório 2014 p. 217), contudo estes projetos nunca chegaram a ser implementados. Sensivelmente deste período surgem a classificação de vários monumentos. A igreja de Nossa Senhora da Ajuda é o primeiro edifício a ser classificado como Imóvel de Interesse Público, através do Decreto $\mathrm{n}^{\circ} 45$ 327, DG, 1. ${ }^{\mathrm{a}}$ série, n. ${ }^{\circ} 251$ de 25 outubro 1963. Segue-se classificação da Fortaleza e da frente abaluartada, inseridas na categoria de Monumento Nacional, (Decreto no 28 536, DG, 1. ․ㅡ série, n. .066 de 22 março 1938 / ZEP / Zona “non aedificandi”, Portaria, DG, 2. ․ㅗ́rie, n. . 71 de 24 março $1967^{*}$ 1). Este conjunto abaluartado estende-se desde Peniche de Baixo até Peniche de Cima, sendo constituído pelos meio-baluartes da Misericórdia, Calçada, São Vicente e Gamboa e pelo Baluarte da Ponte, e pela cortina de muralha (Figura 3). Mais tarde a igreja da Misericórdia, construída ainda na primeira metade do século XVII, é classificada como Imóvel de Interesse Público, ( Decreto no $95 / 78$, DR, 1. ․ㅗ série, n.․ำ 210 de 12 setembro 1978).

Em setembro de 1994, é constituído o grupo de trabalho, Gabinete Técnico Local (GTL), pertencente à Câmara Municipal de Peniche. Este Gabinete coordenado pela Arquitecta Cristina Salvador, é constituído por uma equipa multidisciplinar, incorporando o Engenheiro Civil José Mazarelo, Gabirela F. Silva, assistente social; Filomena Sousa, desenhadora; e Ivete Carmo, administrativa, um ano depois entra para a equipa Duarte Jorge, técnico de informática (Salvador 1996a, pp. 6-7). O GTL teve como principal objetivo a reabilitação e Património Histórico de Peniche, chegando a demarcar duas áreas de interesse prioritário (Salvador 1996 a pp. 1 e 7). Este estudo sobre a malha urbana permitiu realizar inclusive uma caracterização da população residente nas zonas de intervenção (Voz do Mar 21 de Março de 1996b, pp.4-5), e um levanta- 
mento dos logradouros (Salvador 1996 c, p.3). Além do trabalho de caracterização do património, realizou várias sessões de esclarecimento dos trabalhos no jornal local A Voz do Mar como o artigo Património Cultural A Capela de Santo António, referindo à necessidade de reabilitar aquele espaço urbano, incluindo o Jogo da Bola e o fortim de Santo António (Salvador 1995 B, pp. 6-7). Nos inícios do ano de 1996 já estavam concluídos vários projetos ou em fase de conclusão: Levantamento e análise da Área de Intervenção Prioritária zona 2 e 3 (concluído); Levantamento geral e análise de Intervenção Zona 4,5,6 (em conclusão); Levantamento e análise da Área de Intervenção Zona 1, bairro Alto da Vela (levantamento concluído e análise em estudo); Plano de Reabilitação e Ordenamento do Campo da República e Alto da Vela (em fase de candidatura); Regulamento Preliminar de Intervenção Urbanística (concluído e aguardando aprovação); Estudo da pavimentação do Largo 5 de Outubro (estudo prévio); Projeto de Reabilitação e Restauro da Capela de Santo António e fortim de Santo António (Negociação da C.M.P. para aquisição das parcelas); Projeto de Reabilitação e ordenamento do Forte das Cabanas (em curso), Projeto de arranjo do Largo entre Rua José Estevão e Rua Vasco da Gama (em curso); Projeto de reabilitação do Largo envolvente à igreja de São Pedro (em curso); Projeto de reabilitação da gruta da Furninha (estudo prévio) entre outras atividades de sensibilização junto de escolas (Salvador 1996a p.7).

Estes trabalhos permitiram ainda classificar a igrejas de Nossa Senhora da Conceição, São Pedro e capela/ Santuário de Nossa Senhora dos Remédios como Imóvel de Interesse Público, através do Decreto no 2/96, DR, 1. ․ㅗ série, n. ${ }^{\circ} 56$ de 06 março 1996.

Ainda deste período, em 1995 é elaborado pela Câmara Municipal de Peniche o Plano Diretor Municipal sendo dedicado o capítulo IV ao Património. Neste ponto fica clarificado no artigo $22^{\circ}$ o que é Património: "Entende-se por património histórico o conjunto dos bens culturais, sociais e económicos, de carácter natural ou produto da cultura e que estruturam a identidade do concelho". Os Artigos $23^{\circ}$ e $24^{\circ}$ bordam os princípios gerais do património e as suas categorias, dividindo em: a) Imóveis Classificados incluindo os Monumentos Nacionais, Imóveis de Interesse Público e Valores Concelhios; b) Outros Valores a proteger incluindo Núcleos Urbanos, Património Arquitectónico incluindo Edificios ou Conjuntos e Valores Arqueológicos.

O Artigo $25^{\circ}$ clarifica os princípios gerais dos imó- veis classificados alertando para a zona de proteção mínima de $50 m$ bem como a autorização do então Instituto Português do Património Arquitetónico e Arqueológico, bem como no futuro a possível classificação de monumentos de interesse municipal estarem também abrangidos pelas mesmas premissas. Os dois artigos seguintes são sobre a proteção do núcleo histórico, definindo os seus princípios gerais e remete-lo para a proteção da muralha de Peniche, deixando o resto sem proteção.

Em 2009 na redação da Carta Magna surge pela primeira vez um capítulo dedicado ao património com a referência à arqueologia: "No respeita ao património arqueológico, no Museu Municipal de Peniche, existem colecções arqueológicas pré-históricas (nomeadamente relativas à gruta da Furninha) $e$ de achados submarinos (nomeadamente relativos ao naufrágio do S. Pedro de Alcântara), além de um acervo de arqueologia romana ainda em fase de estudo. A Câmara Municipal tem nos seus quadros um arqueólogo que acompanha as obras efetuadas no município e exerce actividade genérica na área da identificação, preservação e valorização do património arqueológico, nas três vertentes acima indicadas: arqueologia pré-histórica, arqueologia romana e arqueologia subaquática. Está em curso o inventário do acervo conservado no Museu, mas não existe carta arqueológica do concelho, nem para a superficie terrestre nem para os seus fundos marinhos" (Carta Magna 2009, p 62).

Sobre o património edificado da cidade destacam apenas a Fortaleza, igreja da Misericórdia, igreja de São Pedro, Santuário de Nossa Senhora dos Remédios, Fonte do Rosário e gruta da Furninha (Carta Magna pp. 124-126). Propondo a criação de uma rota associada ao património militar com interesse e a sua reabilitação (Carta Magna p.136). Atualmente encontra-se em revisão o PDM de 1995.

\section{A ARQUEOLOGIA NA CIDADE}

Os anos 80 do século passado marcam o arranque dos trabalhos arqueológicos na cidade de Peniche, todavia anteriormente existem relatos de achados em algumas partes da cidade. A notícia mais antiga surge no inquérito promovido pela Academia Real da História Portuguesa, em 1721 em que o pároco responde: "Presentemente mandei abrir (que estava fechada a dita casa e olha para a parte do poente), uma porta por onde se dizia principiava a entrada 
do dito tanque e mandei cavar dentro efora bastante altura e se não achou o que pretendia, mais que uns alicerces de pedra e cal, muito juntos uns aos outros, sem proporção de que fossem fundamente para nenhum género de edificio" e mais adiante acrescenta terem sido encontradas duas pedras com inscrições "de letra antiga" que estavam no chafariz e desta forma não era possivel de as ler, todavia existia a referência a que numa dela se podia ler Júlio César (Calado 1996 p.22-23).

Com o terramoto de 1755 e consequente maremoto é posto a descoberto junto ao Portinho do Meio um muro que se encontrava enterrado na areia e que não havia registo do seu conhecimento, tendo sido aproveitada a sua pedra para reparar o cais (Constantino \& alii 2016).

No século XIX é descoberto em Peniche de Cima, num muro próximo à igreja de Nossa Senhora da Ajuda, por Pedro Cervantes Figueira em 1858 um cipo romano (Calado 1991 p.63-64; Calado 1999, p. 67; Venâncio 2001). Ainda neste século realizam-se os primeiros trabalhos arqueológicos em Peniche, promovidos por Nery Delgado na gruta da Furninha, na altura distante do perímetro urbano.

As notícias de achados em Peniche, na parte terrestre, só surgem já nos anos 70 do século XX em três artigos do jornal A Voz do Mar sobre uns canhões encontrados no decorrer das dragagens e ampliação do porto de pesca. Ainda na mesma década inicia-se a investigação sobre o navio espanhol São Pedro de Alcântara, no Porto de Areia Norte, sob a coordenação de Jean Yves Blot e Maria Luisa Blot. Os trabalhos arqueológicos na necrópole associada ao naufrágio deste vaso de guerra em 1786, decorre em 1985 com a prospeção magnética da necrópole e no ano seguinte arrancam os trabalhos arqueológicos prolongando-se até 1988, e retomados em 1993 até 1997 (Blot 2008).

O ano de 1998 marca o início da arqueologia de salvamento e de emergência em Peniche. No decorrer de trabalhos de terraplanagem para a construção de campos de ténis é encontrado um forno romano, na rua Calouste Gulbenkian. As investigações desde então têm sido sistemáticas, seja em escavação seja em laboratório.

No total foram encontrados quatro fornos de produção de ânforas com início no reinado de Augusto. O forno 1 apresenta $3,25 \mathrm{~m}$ de diâmetro interno, conservando uma parede com 1,1m de altura na camara de cozedura. O forno 3 é o maior, apresentan- do 3,95m de diâmetro inteiro (Cardoso e Rodrigues 2005; Cardoso \& alii 2006), os fornos 2 e 4 são mais pequenos e mais destruídos não permitindo avançar com o diâmetro correto (Cardoso \& alii 2016).

Os fornos apresentam planta circular com corredor central aberto no geológico, as paredes rondam os o.8m de espessura, ligadas com argila. As áreas de acesso ao praefurnia dos fornos 1 e 3 estavam protegidas por um telheiro apoiado em muros de alvenaria seca (Cardoso e Rodrigues 2005). As câmaras expunham de uma grelha de tijoleira como separação da fornalha, apoiada em arcos de tijolo perpendiculares à abertura central e separados entres si de forma a permitir uma maior passagem do calor da fornalha para a camara de cozedura (Cardoso \& alii 2018).

O estudo dos materiais permitiu caracterizar a produção cerâmica composta por doze tipos de ânforas, cerâmica comum e pesos de rede. Associado à olaria encontra-se a marca de oleiro Lucio Arvenio Rustico. O encerramento da produção ocorre no início do século III (Cardoso \& alii 2016).

Nas proximidades do Morraçal da Ajuda, foi colocado a descoberto em 2007, na rua Azeredo Perdigão, diversos vestígios associados à época romana. Este sítio arqueológico foi identificado pelo arqueológo camarário no decorrer dos trabalhos de terraplanagem para a construção de um empreendimento. Os trabalhos de escavação ficaram a cargo da empresa Neoépica Arqueologia e Património sob a direção dos arqueólogos Raquel Santos e Tiago Fontes. Foram exumados sobretudo ânforas de produção local, a que se juntam alguns fragmentos de sigillata, cerâmica comum, cavilhas em bronze e placas em chumbo com caracteres possivelmente etiquetas de ânforas que indicavam o seu destino. Durante a escavação foi identificada uma estrutura com vários compartimentos sem que até ao momento se tenha aferido a sua função. Atendendo a sua localização próxima aos fornos romanos e junto à antiga linha de costa poderemos estar perante estruturas de apoio à atividade portuária ou ao complexo de produção. Os dados preliminares apontam para uma cronologia em torno do século I d.C (Neto \& alii 2007).

Durante a ampliação do porto de pesca, na construção dos novos cais, entre Maio de 2001 e Outubro do ano seguinte, decorreu o acompanhamento arqueológico da empreitada. No desenvolvimento dos trabalhos foram identificados vários materiais de cronologia diversas, em contexto secundário, desde a época romana até ao século XX destacando-se 
ânforas do tipo Almagro 50, Dressel 7-11 e Dressel 14, canecas tardo-medievais e materiais de construção. (Venâncio 2005, 2006).

A última década caracteriza-se pela realização de trabalhos arqueológicos durante a construção de novas habitações localizadas nas áreas de proteção dos monumentos (fig.4). Em 2010 procedeu-se às escavações do convento franciscano do Bom Jesus, com a coordenação de Cláudia Cunha. No decorrer dos trabalhos identificou-se um conjunto de estruturas associadas ao convento quinhentista, destacando-se uma fonte do século XVIII e o seu pátio (Cunha \& alii 2012). Em 2012 na Rua Afonso de Albuquerque, foram colocadas a descoberto estruturas e materiais quinhentistas e seiscentistas. O espólio encontra-se atualmente a ser estudado pelos signatários, tendo sido já identificado formas de pão-de-açúcar (Constantino 2017).

Os trabalhos mais recentes permitiram identificar outras realidades até então ausentes no registo arqueológico de Peniche. A intervenção realizada pela Patrimonium, na rua José Estevão ํㅜ 133-135, colocou a descoberto o resto de um tanque de salga de peixe. Associados a esta estrutura estão materiais do século XVI e XVII, como uma majólica, faiança azul sobre azul, loiça Malagueira, pesos de rede, e restos ictiológicos.

Nas intervenções arqueológicas na rua de São Mar$\cos n^{\circ} 17$ e 19 (Rendeiro no prelo), Travessa da Fé no 14 (Filipe 2020) e Rua Afonso de Albuquerque (Filipe 2019) permitiram a identificação pela primeira vez de cisternas destinadas à recolha das águas pluviais. A sua utilização em Peniche encontra-se intimamente relacionada com a carência de água doce que Peniche enfrentou até ao século XX.

Por fim importa salientar a presença de materiais quatrocentistas no decorrer da abertura de sondagens na rua Francisco Seia no 9 (Filipe 2019 b) e de materiais associados a meados do século XVIII no Largo 5 de Outubro no 18 (Filipe 2019 c). Se o primeiro local corresponde à ocupação mais antiga conhecida após a presença romana em Peniche, o segundo poderá estar relacionado com terramoto de 1755 .

\section{CONCLUSÕES}

As leituras dos dados apresentados no decorrer deste trabalho demonstram uma primeira fase, caracterizada pela destruição e alteração do património, nomeadamente as obras verificadas na Av. do Mar, com a afectação do meio-baluarte da Misericórdia, a destruição da capela de São Marcos, Passos da Misericórdia, Paiol e Forte de Nossa Senhora da Vitória e o alargamento dos portões de Peniche de Cima. Em resposta a estes acontecimentos são classificados a Fortaleza (a data prisão política) e a frente abaluartada e a igreja de Nossa Senhora da Ajuda, marcando o início da valorização do património.

Contudo será necessário a chegada de meados dos anos 90 do século XX para se assistir à criação de um gabinete que se debruce sobre os problemas do Património local. A ação do GTL permitiu a classificação de novos monumentos e a elaboração de vários projetos que visavam a valorização do centro-histórico, realidade que não se chegou a verificar na sua totalidade.

Com a viragem de milénio, assistiu-se timidamente à chegada da arqueologia de salvamento. Os trabalhos e a informação produzida, permitem verificar a ocupação romana em Peniche de Cima. Em Peniche de Baixo verifica-se ausência de contextos romanos, remontando os materiais mais antigos para o século XV.

\section{BIBLIOGRAFIA}

BLOT, Jean Yves (2009) - Concerto para Mar e Orquestra. San Pedro de Alcântara, 1786. Edição Câmara Municipal de Peniche.

BLOT, Maria Luísa (2003) - Os Portos na Origem dos Centros Urbanos. Trabalhos de Arqueologia, n.ำ 28, Instituto Português de Arqueologia.

BRUGAL, Jean-Philip, ARGANT, Jacqueline, CRISPIM, José António; FIGUEIREDO, Silvério; SERRA, Alberto; PALMQVIST, Paul (2012) - The Complex Carnivore-rich Assemblages from Furninha (Peniche, Portugal): a Multidisciplinary Approach, in Journal of Taphonomy, Volume 10, pp. 417-438.

BRANDÃO, Raul (2010) - Os pescadores, $2^{\underline{a}}$ Edição, Estante Editora.

CALADO, Mariano (1991) - Peniche na História e na Lenda, $4^{\underline{a}}$ edição. Edição do autor.

CALADO, Mariano (1994) - Da ilha de Peniche. Edição de autor.

CALADO, Mariano (1996) - Peniche no Século XVIII (As Memórias Paroquiais). Edição do autor.

CALADO, Mariano (1999) - Visão Cronológica de Peniche. Edição do autor.

CALADO, Mariano (200o) - Fortificações da Região de Peniche. Edição do autor. 
CARDOSO, Guilherme; RODRIGUES, Severino (2005) Olaria romana do Morraçal da Ajuda. Bombarral, Actas do Congresso A Presença Romana no Oeste, p. 57-64.

CARDOSO, Guilherme; RODRIGUES, Severino; SEPÚLVEDA, Eurico (2006) - A olaria romana do Morraçal da Ajuda. Actas do Simpósio Produção e comércio de Preparados de Piscícolas durante a Proto-História e a Época Romana no Ocidente da Península Ibérica, pp. 253-278.

CARDOSO, Guilherme; RODRIGUES, Severino; SEPÚLVEDA, Eurico; RIBEIRO, Inês (2011) - Vestígios de uma olaria romana no Morraçal da Ajuda - Peniche, PAIDEIA. Revista da Escola Secundária de Peniche, nº 2, pp. 47-58.

CARDOSO, Guilherme; RODRIGUES, Severino; SEPÚLVEDA, Eurico; RIBEIRO, Inês; (2016) - Production during the Principate in Peniche (Portugal). Raw Materials, Kilns and Amphora Typology; in Lusitanian Amphorae: Production and Distribution, Roman and Late Antique Mediterranean Pottery 10, pp. 3-17.

CONSTANTINO, Adriano (2017) - Novos dados acerca das formas de pão-de-açúcar: o caso do estudo das formas descobertas na Rua Afonso de Albuquerque, Peniche (centro de Portugal), in ARNAUD, José e MARTINS, Andrea (coords.) A Arqueologia em Portugal - Estado da Questão, Edição Associação Arqueólogos Portugueses. pp. 1657-1666.

CONSTANTINO, Adriano; ANDRADE, Daniela; LOURENÇO, Inês; RENDEIRO, Luís (2016) - O Terramoto de Lisboa: o caso de Peniche, Arqueologia \& História, Vol. 68, Edição Associação dos Arqueológos Portugueses, pp. 127-138.

CUNHA, Cláudia; VILELA, Carlos; SIMÕES, Sónia; TOMÉ, Tiago; MOREIRA, João; GINJA, Mónica; GONÇALVES, Gerardo (2012) - Convento quinhentista do Bom Jesus de Peniche - primeira intervenção arqueológica, in Velhos $e$ Novos Mundos, Estudos de Arqueologia Moderna, Vol. 1, pp. 517-526.

FILIPE, Vanessa (2019) - Relatório Final, Rua Afonso de Albuquerque s/n, Peniche, texto policopiado.

FILIPE, Vanessa (2019 b) - Relatório Final, Rua Francisco Seia $n^{o}$ 9, Peniche, texto policopiado.

FILIPE, Vanessa (2019 c) - Relatório Final, Largo 5 de Outubro $n^{\circ} 18$, Peniche, texto policopiado.

FRANÇA, José Camarate; ZBYSEWSKI, Georges.; ALMEIDA, Fernando Moitinho de (1960) - Carta Geológica de Portugal, Notícia Explicativa da Folha 26-C Peniche. Serviços Geológicos de Portugal.

GREGÓRIO, Sofia; (2014) - Arquitectura ou revolução: estudos de urbanismo em Peniche: a obra do arquiteto Paulino Montez. Tese de Mestrado apresentado no ISCTE-IUL, edição policopiada.

NETO, M.; REBELO, Paulo.; SANTOS, Raquel; FONTES, Tiago; (2007) - Neoépica Lda: Principais intervenções em 2007. Al madan, IIํㅡ́rie, p. 156.
RENDEIRO, Luís (no prelo) - Relatório Final, Rua de São $\operatorname{Marcos} n^{\circ} 17$ e 19 .

RUSSO, Jorge (2014) - A Pesca da Sardinha em Peniche: 1900-1950, in Jornadas do Mar, Uma onda de Progresso, pp. 212-223.

SALVADOR, Cristina (1995 A) - Reabilitação e Património Histórico em Peniche, in A Voz do Mar, edição nº 910, pp.1-11.

SALVADOR, Cristina (1995 B) - Património Cultural A Capela de Santo António, in A Voz do Mar, edição de 20 de abril, pp. 6-7.

SALVADOR, Cristina (1996a) - Exposição do trabalho do GTL e seminário sobre antropologia marítima, in A Voz do Mar, edição de 19 de janeiro, pp. 6-7.

SALVADOR, Cristina (1996b) - Alguns aspectos sócio-económicos que caracterizam a população residente nas zonas de intervenção prioritária do GTL, in A Voz Do Mar, edição de 21 de março, pp. 4-5.

SALVADOR, Cristina (1996 C) - A face semi escondida do interior dos quarteirões da zona de intervenção prioritária do GTL, in A Voz do Mar, edição de 21 de abril, p. 3 .

VENÂNCIO, Rui (200o) - De uma inscrição encontrada em Peniche à história de uma importante família olisiponense. Conimbriga, XXXIX, pp. 259-273.

VENÂNCIO, Rui (2005) - Relatório de Acompanhamento Arqueológico da Obra de Alargamento do Porto de Pesca de Peniche $2^{\underline{a}}$ fase. Texto policopiado.

VENÂNCIO, Rui (2006) - Acompanhamento Arqueológico da Obra de Alargamento do Porto de Pesca de Peniche: resultados e conclusões. Actas do $3^{\circ}$ Seminário do Património da Região do Oeste, pp.79-9o.

ZBYSZEWSKI, G (1970) - Indústrias Paleolíticas da Região de Peniche. O Arqueólogo Português, serie 3, Vol IV. pp. 19-43.

\section{CARTOGRAFIA}

Carta Geológica de Portugal, folha 26-D (Peniche), Escala 1/ 50 ooo, Direcção Geral de Minas e Serviços Geológicos, Serviços Geológicos.

Carta Militar de Portugal, folha 337 (Peniche), Escala 1/25 ooo, Serviço Cartográfico do Exército

\section{Arquivos}

A Voz do Mar

\section{Biblioteca de Peniche}

Correio Popular

Correio de Peniche 


\section{Biblioteca Nacional}

AZEDO, Eusébio Dias, fl. ca 18oo - Planta da Praça de Peniche, e de parte da Peninsula, em que está situada, com o projecto das obras de fortificação necessarias para a pôr em estado de defensa / levantada de ordem do Sr. Marechal General junto á Real Pessoa pelos oficiaes do Real Corpo de Engenheiros, que comanda o Tenente Coronel do mesmo Corpo Euzebio Dias Azedo, encarregado do dito projecto, e sua execução.

\section{Outros documentos}

Plano Diretor Municipal de 1995

Carta Magna 2009

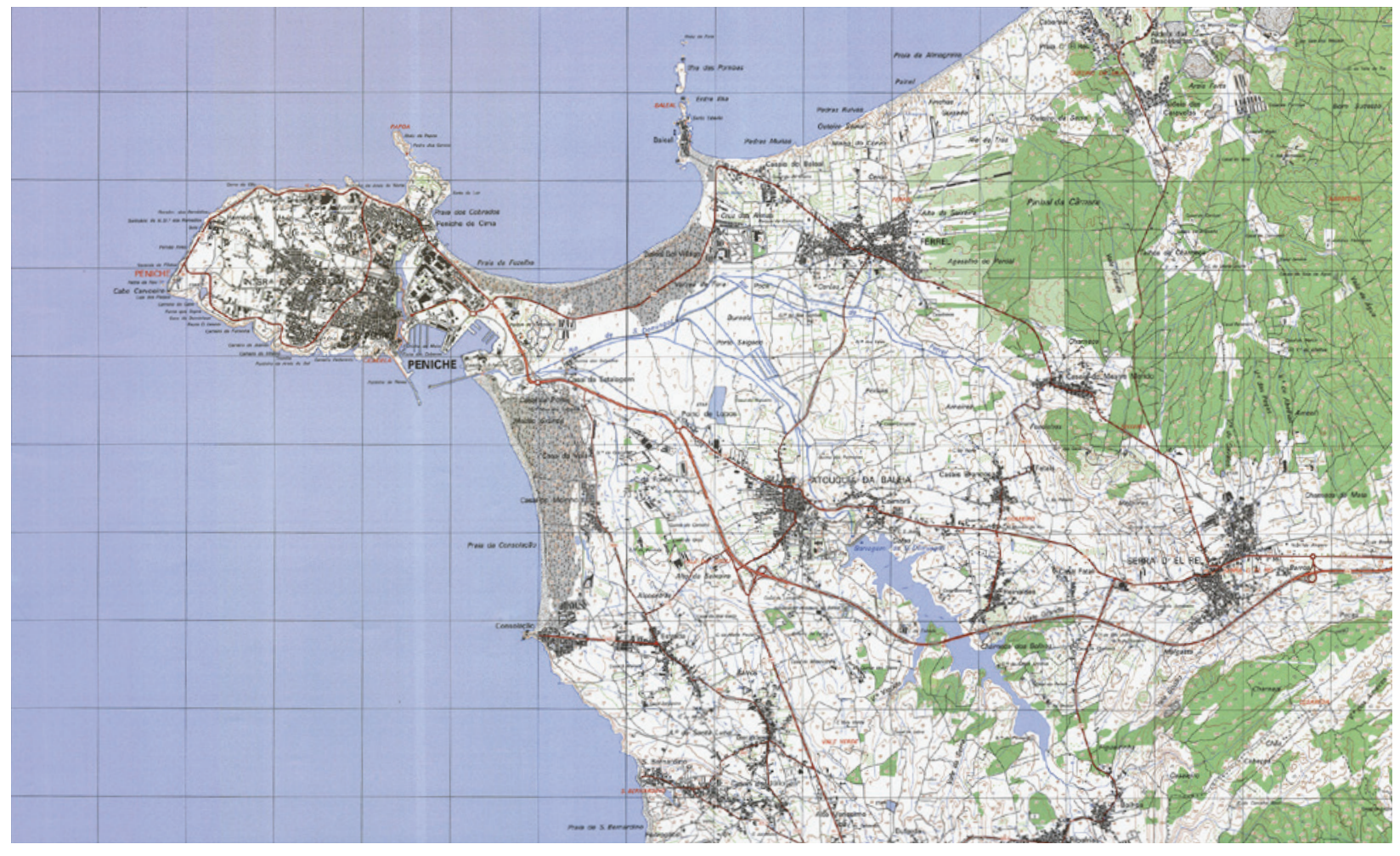

Figura 1 - Localização de Peniche na Carta Militar de Portugal, escala 1: 25 0oo, folha n.․․ 337. 


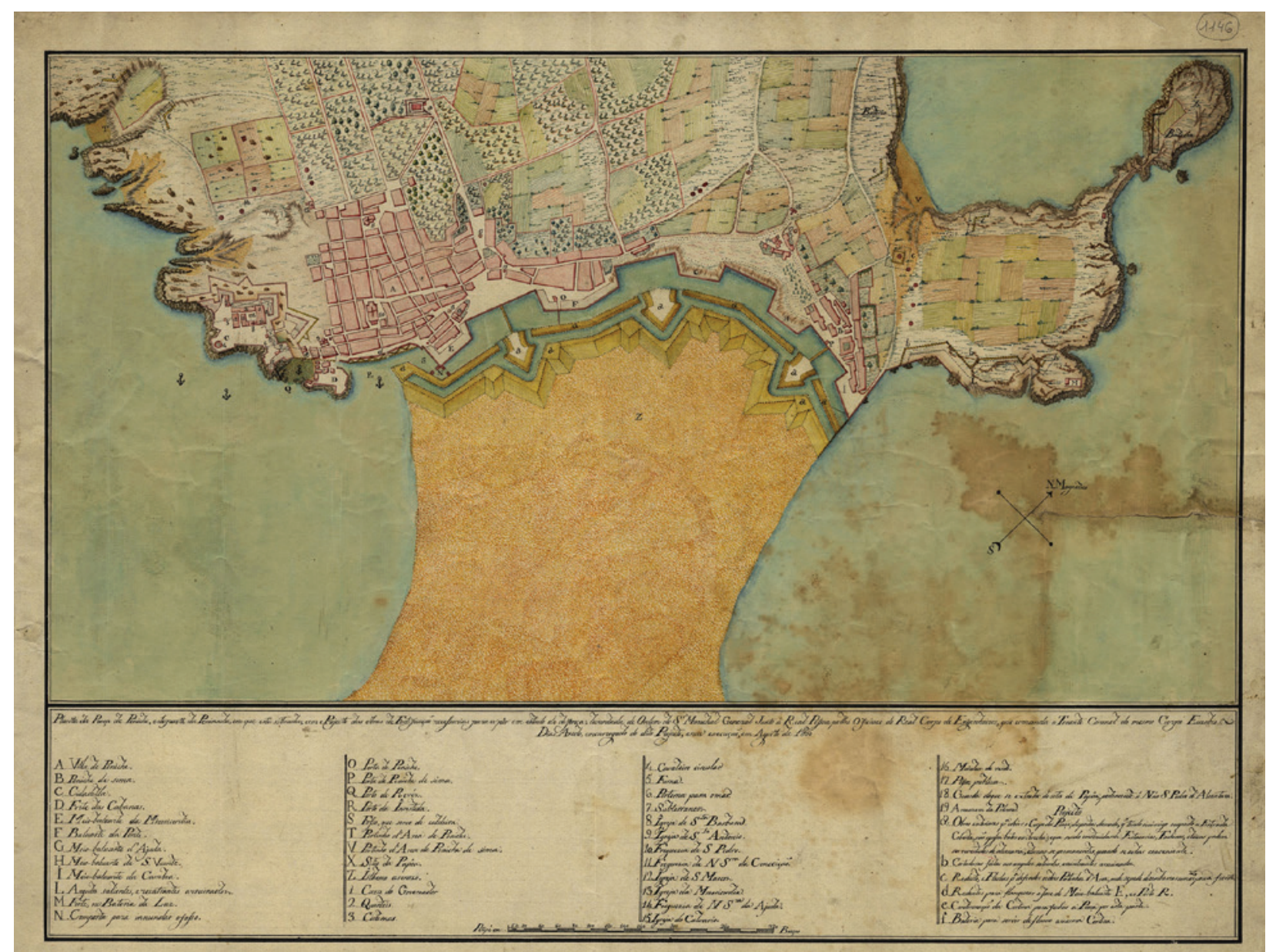

Figura 2 - Planta de Peniche no século XIX, com o projeto de Eusébio Dias Azedo. Na cartografia observam-se dois núcleos habitacionais, Peniche de Baixo e Peniche de Cima. Fonte: Biblioteca Nacional. 


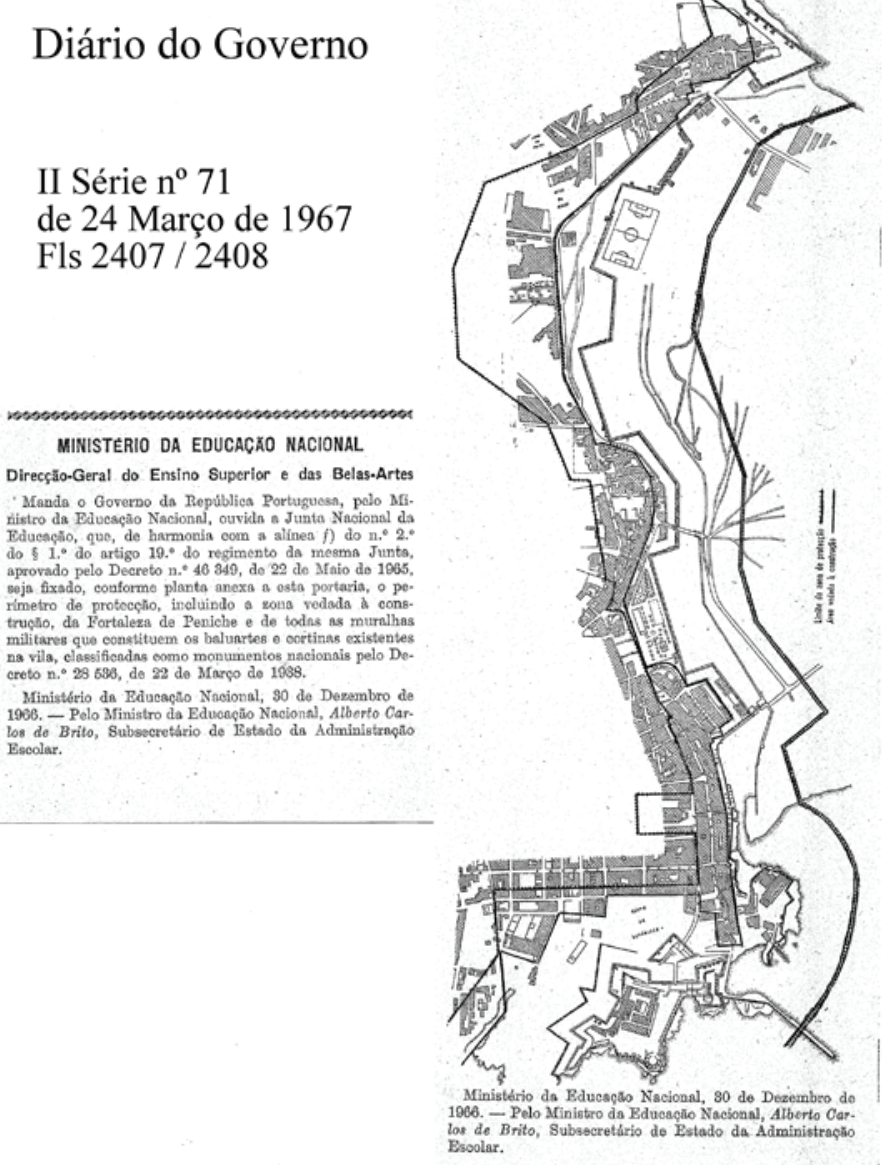

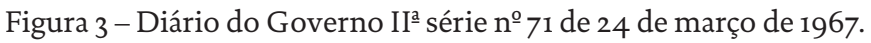

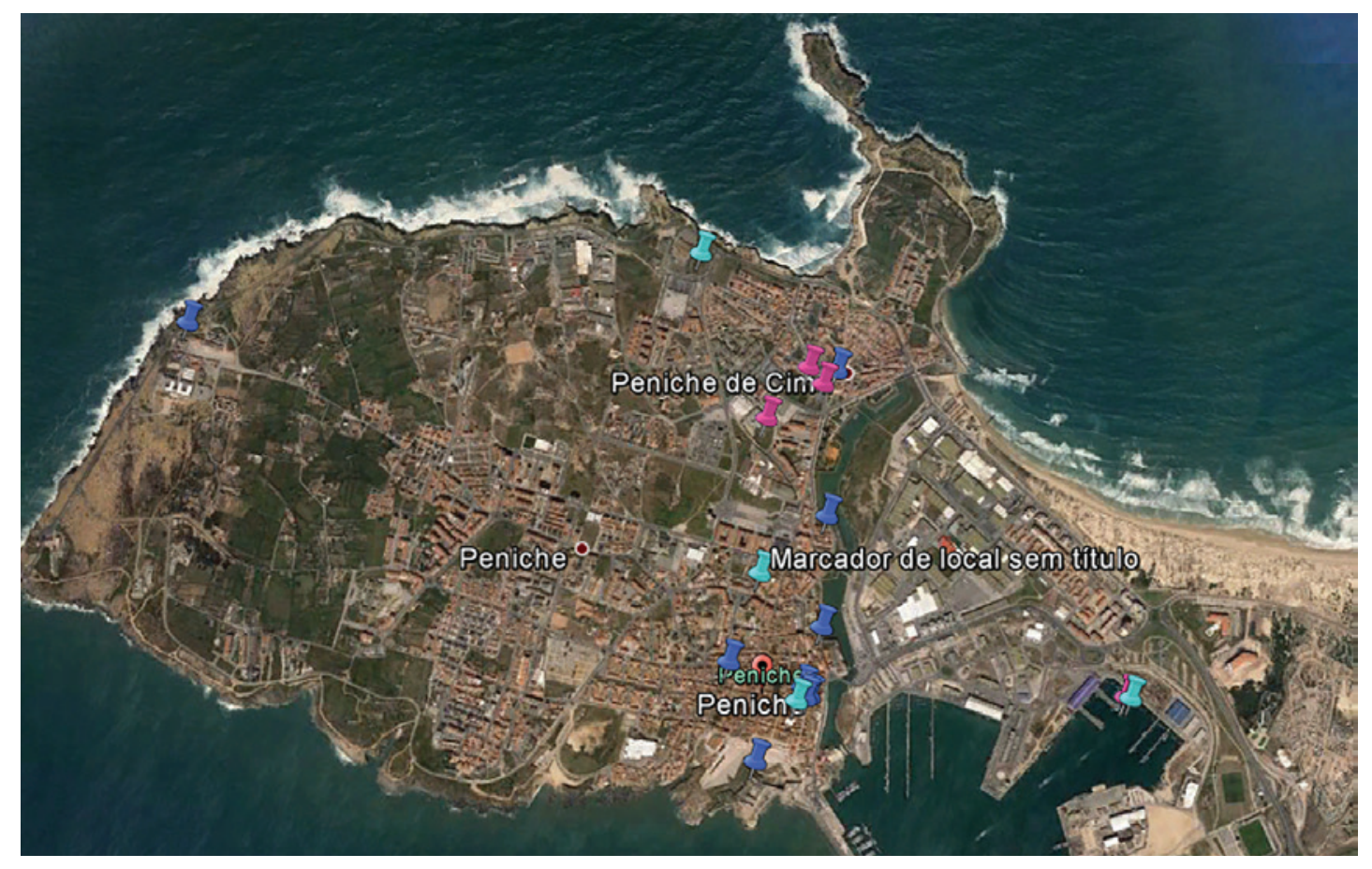

Figura 4 - Localização dos Monumentos classificados a azul escuro, sítios arqueológicos romanos a rosa, e a azul claro sítios de cronologia moderna. Imagem retirada de Google Earth. 



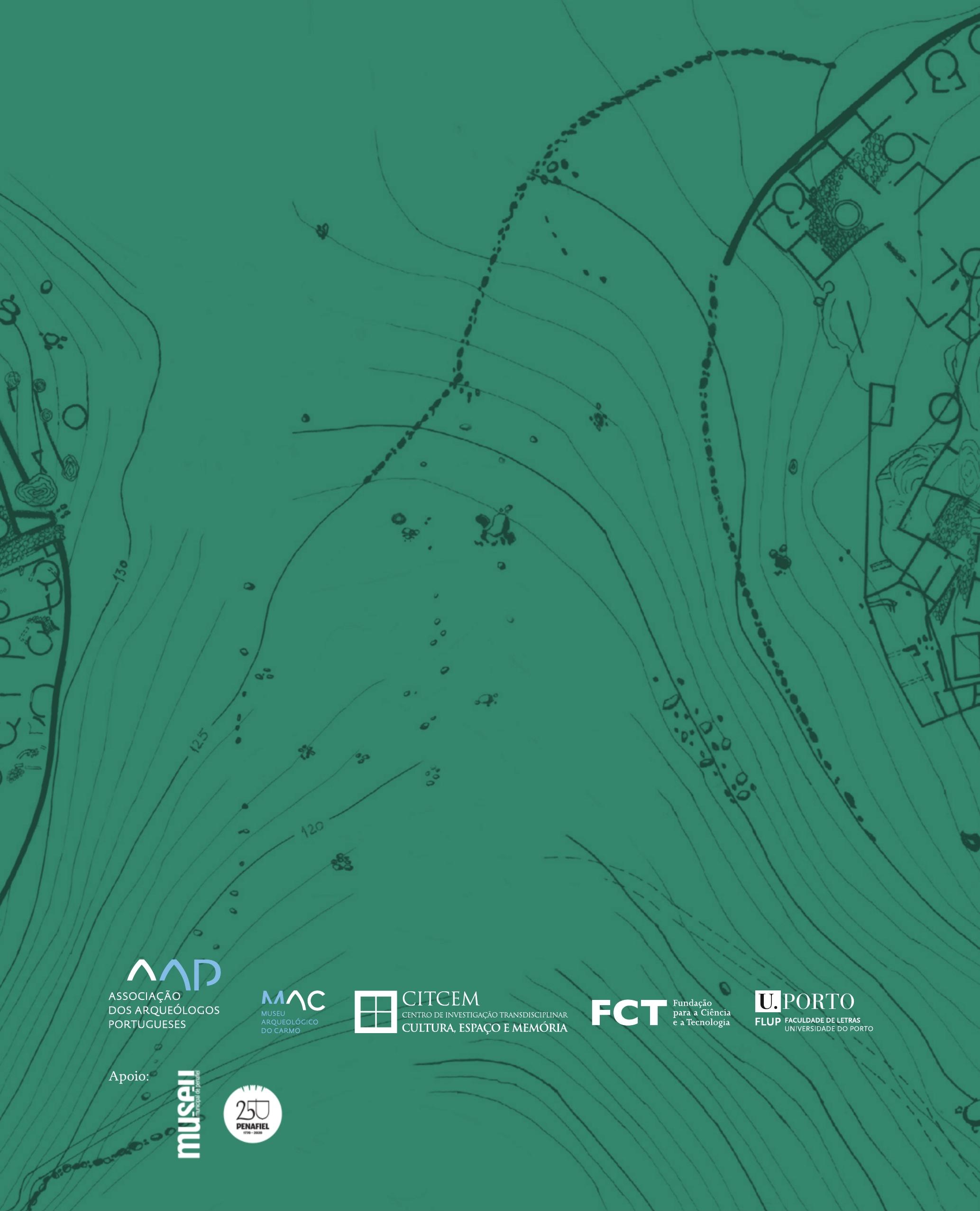

